\title{
EVALUASI SEGREGASI FENOTIPE QUANTITATIVE TRAIT LOCI (QTL) PADA TANAMAN PADI VARIETAS LOKAL DAN NASIONAL DI LINGKUNGAN SAWAH BARU
}

\author{
Rizki Amelia, Saiful Hikam, \& Paul B Timotiwu \\ Jurusan Agroekoteknologi, Fakultas Pertanian Universitas Lampung \\ Jl. Prof. Soemantri Brodjonegoro, No.1, Bandar Lampung 35145 \\ E-mail:rizki_zie666@yahoo.com
}

\begin{abstract}
ABSTRAK
Tanaman padi (Oryza sativa L.) merupakan salah satu tanaman pangan yang diusahakan di Indonesia. Salah satu usaha untuk meningkatkan produksi padi dengan metode quantitative trait loci (QTL). Tujuan penelitian adalah (1) mendapatkan kultivar QTL yang mengalami segregasi fenotipe pada tanaman padi yang ditanam pada lingkungan sawah baru; (2) mendapatkan kultivar QTL yang memiliki ragam genetik dan heritabilitas broad- sense dari tanaman padi yang diteliti di lingkungan sawah baru dan mendapatkan peubah yang dapat dijadikan parameter untuk seleksi langsung dan tidak langsung. Penelitian ini dilaksanakan pada bulan Maret - Mei 2012 di Politeknik Negeri Lampung dan Laboratorium Benih Fakultas Pertanian Universitas Lampung. Rancangan perlakuan disusun dalam kuasi Rancangan Kelompok Teracak Sempurna (RKTS) dengan 3 ulangan untuk setiap sampel. Data terlebih dahulu dicari rata-ratanya. Selanjutnya, data pengamatan diuji dengan uji Bartlett dan Levene untuk kehomogenan data. Bila homogen analisis data dilanjutkan dengan analisis ragam. Hasil penelitian menunjukkan bahwa (1) segregasi fenotipe muncul di lingkungan sawah baru pada tanaman padi varietas IR64 yang merupakan varietas nasional. Segregasi fenotipe terlihat dari parameter tinggi tanaman dan jumlah anakan yang tidak sama pada tanaman padi yang ditanam di lingkungan sawah baru; (2) Keragaman genetik dan heritabilitas yang tinggi terlihat pada semua varietas baik varietas lokal maupun varietas nasional yang ditanam di lingkungan sawah baru dan seleksi langsung ditunjukkan oleh parameter produksi, sedangkan seleksi tidak langsung ditujukkan oleh parameter bobot gabah isi, bobot gabah total, dan jumlah bulir isi pada varietas padi lokal dan nasional di lingkungan sawah baru.
\end{abstract}

Kata kunci : heritabilitas, padi, QTL, ragam genetik

\section{PENDAHULUAN}

Padi (Oryza sativa L.) merupakan makanan pokok bagi sebagian besar penduduk Indonesia. Permintaan akan komoditas ini dari tahun ke tahun mengalami lonjakan sejalan dengan bertambahnya jumlah penduduk. Hal ini mengharuskan petani untuk meningkatkan produktivitas padi untuk memenuhi kebutuhan pangan masyarakat di Indonesia. Salah satu cara meningkatkan produksi tanaman padi adalah dengan menanam varietas unggul yang dapat menghasilkan produksi lebih tinggi serta menghasilkan padi dengan kualitas yang terbaik.

Varietas unggul galur murni dapat dibuat dengan menyilangkan dua genotipe padi yang berbeda untuk menggabungkan sifat-sifat unggul dari keduanya. Hasil persilangan ditanam dan secara alami akan terjadi perkawinan sendiri dalam satu tanaman. Hasilnya ditanam kembali dan akan sangat bervariasi karena terjadi segregasi gen-gen di dalamnya.

Segregasi yang terjadi pada tanaman padi yang dapat terlihat secara visual adalah segregasi fenotipe yang meliputi antara lain, tinggi tanaman dan jumlah anakan. Segregasi fenotipe dapat terlihat apabila tanaman padi yang ditanam di lahan budidaya memiliki tinggi yang tidak seragam dan jumlah anakan yang berbeda untuk tiap-tiap rumpun padi. Nilai fenotipe suatu tanaman tidak hanya terdiri atas pengaruh genotipe tetapi juga oleh pengaruh lingkungan dan interaksi genotipe dan lingkungan (Falconer dan Mackay, 1996). Salah satu cara untuk mengendalikan sifat-sifat gen tanaman padi yang ditanam tersebut adalah dengan menggunakan metode analisis quantitative trait loci atau disebut metode QTL. Pemetaan QTL adalah upaya untuk mengidentifikasi lokasi di dalam segmen DNA di mana terdapat gen yang mengendalikan suatu karakter kuantitatif yang ditargetkan.

Selain itu, faktor lingkungan juga dapat mempengaruhi pertumbuhan dan produksi tanaman padi. Penelitian ini dilakukan di lingkungan ketiga atau lahan sawah baru yang merupakan sawah irigasi. Lingkungan ketiga berbeda dengan lingkungan pertama (Tulang Bawang Barat) yang merupakan sawah tadah hujan dan lingkungan kedua (Way Jepara) yang merupakan sawah 
irigasi teknis. Berdasarkan identifikasi dan pembatasan masalah, penelitian ini dilakukan untuk menjawab masalah yang dirumuskan dalam pertanyaan: (1) apakah terjadi segregasi fenotipe pada tanaman padi yang ditanam pada lingkungan sawah baru?, (2) apakah terdapat kultivar QTL yang memiliki ragam genetik dan heritabilitas broad- sense dari tanaman padi yang diteliti di lingkungan sawah baru?, dan (3) Apakah terdapat peubah yang dapat dijadikan parameter untuk seleksi langsung dan tidak langsung?.

\section{BAHAN DAN METODE}

Penelitian ini bertempat di Politeknik Negeri Lampung dan Laboratorium Benih Fakultas Pertanian, Universitas Lampung. Penelitian ini berlangsung dari bulan Maret -Mei 2012. Bahan yang digunakan dalam penelitian ini adalah 9 varietas padi, yaitu varietas Sarinah (V1), Mutiara (V2), Gendut (V3), IR-64 (V4), PB Bogor (V5), Ciliwung (V6), Ciherang (V7), Kesit (V8), dan Tewe (V9). Dalam penelitian ini hanya menggunakan varietas padi lokal dan nasional, yaitu varietas Sarinah, Mutiara, Gendut dan IR-64. Alat yang digunakan dalam penelitian ini adalah bambu sepanjang $150 \mathrm{~cm}$, cat, kamera digital, alat tulis, meteran, seed blower, oven dan timbangan digital.

Lahan penelitian diolah menggunakan bajak sebelum ditanami padi. Benih padi terlebih dulu disemai sebelum ditanam di lahan penelitian. Benih padi yang siap tanam dipindahkan ke lubang tanam dengan jarak tanam $25 \mathrm{~cm} \times 25 \mathrm{~cm}$ dengan dua benih padi per satu lubang. Pupuk yang digunakan antara lain Urea, SP36 dan KCl. Pupuk Urea diberikan sebanyak $300 \mathrm{~kg} \mathrm{ha}^{-1}$ dan diaplikasikan sebanyak 3 kali pada saat awal tanam, masa vegetatif, dan pada awal pembungaan. Pupuk SP36 diberikan sebanyak $100 \mathrm{~kg} \mathrm{ha}^{-1}$ yang diaplikasikan sebanyak 1 kali pada saat awal tanam. Pupuk $\mathrm{KCl}$ diberikan sebanyak $100 \mathrm{~kg} \mathrm{ha}^{-1}$ yang diaplikasikan sebanyak 2 kali yaitu pada awal tanam dan pada masa pembungaan. Pengendalian hama menggunakan insektisida Regent Spontan yang diaplikasikan seminggu sekali. Penetapan sampel dilakukan pada saat masa vegetatif. Penetapan sampel pertama untuk menetukan QTL pertama yaitu jumlah anakan dan ketahanan terhadap penyakit blast. Penetapan sampel kedua dilakukan 2 minggu setelah penetapan sampel pertama. Penetapan sampel kedua untuk menentukan QTL kedua yaitu jumlah bulir. Penetapan sampel ketiga dilakukan saat masa berbunga. Penetapan sampel ketiga untuk menentukan QTL ketiga yaitu tinggi tanaman dan kecepatan waktu berbunga. Panen dilakukan saat masa berbunga $<50 \%$, panen dilakukan dengan cara diarit dan kemudian dirontokkan dari malainya dengan cara dipukulkan ke papan. Padi yang telah dipanen kemudian dikeringkan dengan cara dijemur selama seminggu hingga kadar air berkurang sebanyak $80 \%$ kemudian padi disimpan di ruang penyimpanan.

Penelitian ini menggunakan rancangan perlakuan kuasi RKTS (Rancangan Kelompok Teracak Sempurna) dengan 3 ulangan. Masing masing ulangan terdiri dari 3 sampel tanaman. Data terlebih dahulu dicari rataratanya. Selanjutnya, data pengamatan diuji dengan uji Bartlett dan Levene untuk kehomogenan data. Bila homogen analisis data dilanjutkan dengan analisis ragam. Pengujian ANOVA menggunakan software Statistic Analysis System (SAS) dan korelasi menggunakan software Minitab 14. Besarnya ragam genetik $\left(\sigma^{2} \mathrm{~g}\right)$, heritabilitas broad-sense $\left(\mathrm{h}^{2} \mathrm{bs}\right)$ yang diduga berdasarkan kuadrat nilai tengah harapan pada hasil analisis ragam dan rancangan percobaan yang digunakan sesuai model matematika berdasarkan Hallauer dan Miranda.

Variabel pengamatan pada penelitian ini yaitu tinggi tanaman, jumlah anakan, bobot gabah isi, bobot gabah total per-rumpun, bobot 100 butir gabah isi dengan kadar air $5 \%$, jumlah gabah isi dan produksi (ton/ha)

\section{HASIL DAN PEMBAHASAN}

Rekapitulasi kuadrat nilai tengah dari fase vegetatif dan generatif dari kultivar QTL yang ditanam ditampilkan pada Tabel 1. Tinggi tanaman yang merupakan fase vegetatif menunjukkan hasil yang signifikan untuk varietas, QTL dan varietas QTL. Pada fase generatif yang ditunjukkan oleh parameter bobot gabah isi, bobot gabah total, bobot 100 butir, jumlah bulir isi dan produksi menunjukkan hasl yang signifikan untuk varietas dan varietasQTL, sedangkan QTL mendapatkan hasil yang signifikan pada parameter jumlah gabah isi. Hal ini menunjukkan bahwa faktor lingkungan tidak mempengaruhi pertumbuhan kultivar QTL yang ditanam sedangkan faktor gen mempengaruhi pertumbuhan dan produksi dari kultivar QTL yang ditanam. Menurut Pinaria (1995) dalam Syukur et al. (2011), keragaman genetik suatu populasi tergantung pada apakah populasi tersebut merupakan generasi bersegregasi dari suatu persilangan, pada generasi ke berapa, dan bagaimana latar belakang genetiknya. Keragaman genetik dan heritabilitas sangat bermanfaat dalam proses seleksi.

Hasil penelitian menunjukan bahwa varietas IR64 yang merupakan varietas nasional menghasilkan produksi padi yang lebih rendah dibandingkan dengan tiga varietas lain yang merupakan varietas lokal (Gendut dan Mutiara), sedangkan varietas Sarinah yang 
merupakan varietas nasional mendapatkan produksi yang cukup tinggi dibandingkan varietas IR64 (Tabel 2). Pada Tabel 3 peringkat berdasarkan $\mathrm{BNJ}_{0,05}$ untuk QTL, QTL sudut anakan dan jumlah bulir mendapatkan peringkat pertama, sedangkan tinggi tanaman mendapatkan peringkat kedua. Pada Tabel 4 peringkat berdasarkan $\mathrm{BNJ}_{0.05}$ untuk varietas QTL, varietas QTL Mutiara Sudut Anakan dan Gendut Sudut Anakan menempati peringkat pertama sedangkan Mutiara jumlah bulir, IR64 tinggi tanaman dan mutiara tinggi tanaman berada di peringkat kedua.

Lewis dan Christiansen(1981) dalam Pradnyawathi (2012) menyatakan bahwa tanaman tumbuh dan berkembang sebagai hasil saling pengaruh mempengaruhi antara potensi genetik tanaman dengan lingkungan di mana tanaman tumbuh. Hal itu disimbolkan sebagai $\mathrm{P}=\mathrm{G} \times \mathrm{E}$, dimana $\mathrm{P}=$ fenotipe (sedianya berkembang), $\mathrm{G}=$ genotipe (potensi genetik), dan $\mathrm{E}=$ lingkungan (seperti tanah, air, cahaya matahari, suhu, dan lain-lain).

Nilai koefisien keragaman genetik (KKG) berada di kisaran $<10 \%$ yang berarti pengaruh lingkungan dapat diabaikan sehingga yang berpengaruh adalah faktor gen (Tabel 5). Tabel 6 menunjukkan nilai KKG yg berada di kisaran $<10 \%$ seperti pada Tabel 5 yang menandakan bahwa faktor lingkungan tidak berpengaruh sehingga

Tabel 1. Rekapitulasi kuadrat nilai tengah untuk peubah vegetatif dan generatif

\begin{tabular}{|c|c|c|c|c|c|c|c|c|}
\hline $\begin{array}{c}\text { Sumber } \\
\text { keragaman }\end{array}$ & $\begin{array}{c}\text { Derajat } \\
\text { kebebasan }\end{array}$ & $\begin{array}{c}\text { Tinggi } \\
\text { tanaman } \\
(\mathrm{cm})\end{array}$ & $\begin{array}{l}\text { Jumlah } \\
\text { anakan }\end{array}$ & $\begin{array}{l}\text { Bobot } \\
\text { gabah isi } \\
\text { (g) }\end{array}$ & $\begin{array}{l}\text { Bobot } \\
\text { gabah } \\
\text { total }(\mathrm{g})\end{array}$ & $\begin{array}{c}\text { Bobot } 100 \\
\text { butir gabah } \\
\text { isi }(\mathrm{g})\end{array}$ & $\begin{array}{l}\text { Jumlah } \\
\text { gabah isi }\end{array}$ & $\begin{array}{l}\text { Produksi } \\
\left(\mathrm{t} \mathrm{ha}^{-1}\right)\end{array}$ \\
\hline Ulangan & 2 & 1,44 & 1,75 & 2,01 & 2,02 & 0,07 & 656 & 0,032 \\
\hline Varietas & 3 & $833,36^{* *}$ & $201,53 * *$ & $235,23 *$ & $481,49 * *$ & $1,93^{*}$ & 179155,8 & $3,85^{*}$ \\
\hline QTL & 2 & $400,97 * *$ & 2,99 & 106,85 & 116,13 & 0,34 & $443440,62 *$ & 1,75 \\
\hline Varietas QTL & 6 & $906,47 * *$ & $30,78^{*}$ & $278,60 * *$ & $330,02 * *$ & $4,58 * *$ & 56414,41 & $4,56 * *$ \\
\hline Galat & 22 & 57,46 & 8,07 & 55,24 & 68,92 & 0,49 & 95158 & 0,90 \\
\hline Total & 35 & & & & & & & \\
\hline KK\% & & 5,80 & 9,53 & 12,96 & 11,80 & 12,12 & 14,41 & 12,97 \\
\hline Xbar & & 130,6 & 29,8 & 57,31 & 70,3 & 5,79 & 2140 & 7,34 \\
\hline
\end{tabular}

Tabel 2. Tabel peringkat berdasarkan $\mathrm{BNJ}_{0.05}$ untuk varietas

\begin{tabular}{lccccccccc}
\hline Varietas & $\begin{array}{c}\text { Tinggi } \\
\text { tanaman } \\
(\mathrm{cm})\end{array}$ & $\begin{array}{c}\text { Jumlah } \\
\text { anakan }\end{array}$ & $\begin{array}{c}\text { Bobot } \\
\text { gabah isi } \\
(\mathrm{g})\end{array}$ & $\begin{array}{c}\text { Bobot } \\
\text { gabah } \\
\text { total }(\mathrm{g})\end{array}$ & $\begin{array}{c}\text { Bobot } 100 \\
\text { butir gabah } \\
\text { isi }(\mathrm{g})\end{array}$ & $\begin{array}{c}\text { Jumlah } \\
\text { gabah isi }\end{array}$ & $\begin{array}{c}\text { Produksi } \\
\left(\mathrm{t} \mathrm{ha}^{-1}\right)\end{array}$ & $\begin{array}{c}\text { Jumlah } \\
\text { a }\end{array}$ & Peringkat \\
\hline Sarinah & 121,98 & 24,92 & $56,35 \mathrm{a}$ & $69,12 \mathrm{a}$ & $5,73 \mathrm{a}$ & $2114,8 \mathrm{a}$ & $7,21 \mathrm{a}$ & 5 & 1 \\
Mutiara & $144,13 \mathrm{a}$ & 31,56 & $62,09 \mathrm{a}$ & $78,55 \mathrm{a}$ & 5,38 & $2279,2 \mathrm{a}$ & $7,95 \mathrm{a}$ & 5 & 1 \\
Gendut & 130,16 & 27,14 & $60,26 \mathrm{a}$ & $72,51 \mathrm{a}$ & $6,45 \mathrm{a}$ & $2211,9 \mathrm{a}$ & $7,7 \mathrm{a}$ & 5 & 1 \\
IR64 & 126,12 & $35,56 \mathrm{a}$ & 50,54 & 61,02 & $5,60 \mathrm{a}$ & $1954,1 \mathrm{a}$ & 6,47 & 3 & 2 \\
\hline BNJ & 9,92 & 3,72 & 9,73 & 10,87 & 0,91 & 403,8 & 1,24 & & \\
\hline
\end{tabular}

Tabel 3. Tabel peringkat berdasarkan $\mathrm{BNJ}_{0.05}$ untuk QTL

\begin{tabular}{lccccccccc}
\hline \multicolumn{1}{c}{ QTL } & $\begin{array}{c}\text { Tinggi } \\
\text { tanaman } \\
(\mathrm{cm})\end{array}$ & $\begin{array}{c}\text { Jumlah } \\
\text { anakan }\end{array}$ & $\begin{array}{c}\text { Bobot } \\
\text { gabah } \\
\text { isi }(\mathrm{g})\end{array}$ & $\begin{array}{c}\text { Bobot } \\
\text { gabah } \\
\text { total }(\mathrm{g})\end{array}$ & $\begin{array}{c}\text { Bobot 100 } \\
\text { butir gabah } \\
\text { isi }(\mathrm{g})\end{array}$ & $\begin{array}{c}\text { Jumlah } \\
\text { gabah isi }\end{array}$ & $\begin{array}{c}\text { Produksi } \\
\left.(\mathrm{t} \mathrm{ha})^{-1}\right)\end{array}$ & $\begin{array}{c}\text { Jumlah } \\
\mathrm{a}\end{array}$ & Peringkat \\
\hline Sudut anakan & $136,69 \mathrm{a}$ & $30,00 \mathrm{a}$ & $56,61 \mathrm{a}$ & $70,29 \mathrm{a}$ & $5,84 \mathrm{a}$ & $2205,7 \mathrm{a}$ & $7,24 \mathrm{a}$ & 7 & 1 \\
Jumlah bulir & $129,91 \mathrm{a}$ & $29,23 \mathrm{a}$ & $60,58 \mathrm{a}$ & $73,42 \mathrm{a}$ & $5,92 \mathrm{a}$ & $2290,8 \mathrm{a}$ & $7,75 \mathrm{a}$ & 7 & 1 \\
Tinggi tanaman & 125,19 & $30,16 \mathrm{a}$ & $54,74 \mathrm{a}$ & $67,19 \mathrm{a}$ & $5,60 \mathrm{a}$ & 1923,5 & $7,00 \mathrm{a}$ & 5 & 2 \\
\hline BNJ & 7,77 & 2,91 & 7,62 & 8,51 & 0,72 & 316,3 & 0,97 & & \\
\hline
\end{tabular}


yang mempengaruhi paling banyak adalah faktor gen. Tabel 7 menunjukkan nilai KKG yang berada di kisaran $<10 \%$ yang berarti pengaruh lingkungan tidak dapat diabaikan. Namun, nilai KKG pada Tabel 7 memiliki sebaran yang tidak luas sehingga pengaruh lingkungan tidak terlalu besar dan masih didominasi oleh faktor gen. Keragaman genetik dapat dihitung dengan menetapkan nilai koefisien keragaman genetik (KKG) absolut (Murdaningsih et al., 1990 dalam Hapsari et al., 2010).
Nilai absolut keragaman genetik yang rendah adalah 0 $-6,7 \%$, agak rendah $6,7-13,57 \%$, cukup tinggi 13,5 $20,2 \%$, dan tinggi $20,2-26,9 \%$.

Korelasi positif ditunjukkan oleh tinggi tanaman dengan jumlah anakan serta bobot gabah total dengan jumlah anakan, tinggi tanaman dan bobot gabah isi, sedangkan bobot 100 butir berkorelasi positif terhadap bobot gabah total dan bobot gabah isi (Tabel 8).

Tabel 4. Tabel peringkat berdasarkan $\mathrm{BNJ}_{0.05}$ untuk Varietas QTL

\begin{tabular}{|c|c|c|c|c|c|c|c|c|c|}
\hline Varietas QTL & $\begin{array}{l}\text { Tinggi } \\
\text { tanaman } \\
(\mathrm{cm})\end{array}$ & $\begin{array}{l}\text { Jumlah } \\
\text { anakan }\end{array}$ & $\begin{array}{l}\text { Bobot } \\
\text { gabah } \\
\text { isi }(\mathrm{g})\end{array}$ & $\begin{array}{l}\text { Bobot } \\
\text { gabah } \\
\text { total }(\mathrm{g})\end{array}$ & $\begin{array}{c}\text { Bobot } 100 \\
\text { butir gabah } \\
\text { isi }(\mathrm{g})\end{array}$ & $\begin{array}{l}\text { Jumlah } \\
\text { gabah isi }\end{array}$ & $\begin{array}{l}\text { Produksi } \\
\left(\mathrm{t} \mathrm{ha}^{-1}\right)\end{array}$ & $\begin{array}{c}\text { Jumlah } \\
\text { a }\end{array}$ & Peringkat \\
\hline $\begin{array}{l}\text { Sarinah Sudut } \\
\text { Anakan }\end{array}$ & 115,30 & 22,37 & $\begin{array}{c}65,26 \\
a\end{array}$ & $76,76 \mathrm{a}$ & 5,95 & $2258,1 \mathrm{a}$ & $8,35 \mathrm{a}$ & 4 & 3 \\
\hline $\begin{array}{l}\text { Sarinah Jumlah } \\
\text { Bulir }\end{array}$ & 117,19 & 24,73 & $\begin{array}{c}57,52 \\
\mathrm{a}\end{array}$ & $69,38 \mathrm{a}$ & 5,82 & $2130,6 \mathrm{a}$ & 7,36 & 3 & 4 \\
\hline $\begin{array}{l}\text { Sarinah Tinggi } \\
\text { Tanaman }\end{array}$ & $\begin{array}{c}133,43 \\
\mathrm{a}\end{array}$ & 27,65 & 46,28 & 61,22 & 5,42 & $1955,7 \mathrm{a}$ & 5,92 & 2 & 5 \\
\hline $\begin{array}{l}\text { Mutiara Sudut } \\
\text { Anakan }\end{array}$ & $\begin{array}{c}154,13 \\
\mathrm{a}\end{array}$ & $35,08 \mathrm{a}$ & $\begin{array}{c}61,17 \\
a\end{array}$ & $82,26 a$ & 5,05 & $2386,7 \mathrm{a}$ & $7,83 \mathrm{a}$ & 6 & 1 \\
\hline $\begin{array}{l}\text { Mutiara Jumlah } \\
\text { Bulir }\end{array}$ & 126,50 & $31,31 \mathrm{a}$ & $\begin{array}{c}55,94 \\
\mathrm{a}\end{array}$ & $66,70 \mathrm{a}$ & 4,87 & $2516,7 \mathrm{a}$ & $8,85 \mathrm{a}$ & 5 & 2 \\
\hline $\begin{array}{l}\text { Mutiara Tinggi } \\
\text { Tanaman }\end{array}$ & 126,50 & 28,30 & $\begin{array}{c}55,94 \\
a\end{array}$ & $66,70 \mathrm{a}$ & $6,21 \mathrm{a}$ & $1934,2 \mathrm{a}$ & $7,16 \mathrm{a}$ & 5 & 2 \\
\hline $\begin{array}{l}\text { Gendut Sudut } \\
\text { Anakan }\end{array}$ & 122,99 & $29,83 \mathrm{a}$ & $\begin{array}{c}59,91 \\
\mathrm{a}\end{array}$ & $71,61 \mathrm{a}$ & $8,12 \mathrm{a}$ & $2102,6 \mathrm{a}$ & $7,67 \mathrm{a}$ & 6 & 1 \\
\hline $\begin{array}{l}\text { Gendut Jumlah } \\
\text { Bulir }\end{array}$ & 130,82 & 25,04 & $\begin{array}{c}67,12 \\
a\end{array}$ & $79,69 \mathrm{a}$ & $6,23 \mathrm{a}$ & 2397,6 a & $8,59 \mathrm{a}$ & 5 & 2 \\
\hline $\begin{array}{l}\text { Gendut Tinggi } \\
\text { Tanaman }\end{array}$ & $\begin{array}{c}136,68 \\
a\end{array}$ & 26,56 & $\begin{array}{c}53,77 \\
a\end{array}$ & $66,24 \mathrm{a}$ & 5,00 & $2135,6 \mathrm{a}$ & $6,88 \mathrm{a}$ & 5 & 2 \\
\hline $\begin{array}{l}\text { IR64 Sudut } \\
\text { Anakan }\end{array}$ & $\begin{array}{c}154,34 \\
\mathrm{a}\end{array}$ & $32,74 \mathrm{a}$ & 40,10 & 50,51 & 4,26 & 2075,6 a & 5,13 & 3 & 4 \\
\hline $\begin{array}{l}\text { IR64 Jumlah } \\
\text { Bulir }\end{array}$ & 119,87 & $35,82 \mathrm{a}$ & $\begin{array}{c}48,52 \\
\mathrm{a}\end{array}$ & 57,93 & $6,79 \mathrm{a}$ & $2118,2 \mathrm{a}$ & 6,21 & 4 & 3 \\
\hline $\begin{array}{l}\text { IR64 Tinggi } \\
\text { Tanaman }\end{array}$ & 104,16 & $38,11 \mathrm{a}$ & $\begin{array}{c}62,98 \\
\mathrm{a}\end{array}$ & $74,62 \mathrm{a}$ & 5,76 & $1668,7 \mathrm{a}$ & $8,06 \mathrm{a}$ & 5 & 2 \\
\hline BNJ & 22,51 & 8,44 & 22,07 & 24,66 & 2,09 & 916,2 & 2,83 & & \\
\hline
\end{tabular}

Tabel 5. Pendugaan ragam genetik, heritabilitas, dan koefisien keragaman genetik untuk varietas

\begin{tabular}{|c|c|c|c|}
\hline Peubah & $\sigma^{2} \mathrm{v} \pm \mathrm{GB}^{2} \mathrm{v}$ & $\mathrm{h}^{2} \mathrm{v} \% \pm \mathrm{GBh}^{2} \mathrm{v} \%$ & $\mathrm{KKgv} \%$ \\
\hline Tinggi tanaman & $\pm 9,21 * *$ & $93,11 \pm 9,94 * *$ & 7,11 \\
\hline Jumlah anakan & $\pm 2,23 * *$ & $96,00 \pm 9,94 * *$ & 15,56 \\
\hline Bobot gabah isi & $\pm 2,61 * *$ & $76,52 \pm 10,00^{* *}$ & 7,80 \\
\hline Bobot gabah total & $\pm 5,33 * *$ & $85,69 \pm 9,96^{* *}$ & 9,63 \\
\hline Bobot 100 butir gabah isi & $0,16 \pm 0,02 * *$ & $74,61 \pm 10,00 * *$ & 6,91 \\
\hline Jumlah gabah isi & $9333,09 \pm 2035,60 * *$ & $46,89 \pm 10,23 * *$ & 4,51 \\
\hline Produksi & $0,33 \pm 0,04 * *$ & $76,62 \pm 9,99 * *$ & 7,80 \\
\hline
\end{tabular}


Tabel 6. Pendugaan ragam genetik, heritabilitas, dan koefisien keragaman genetik untuk QTL

\begin{tabular}{lccc}
\hline Peubah & $\sigma^{2} \mathrm{q} \pm \mathrm{GB}^{2} \mathrm{q}$ & $\mathrm{h}^{2} \mathrm{q} \% \pm \mathrm{GBh}^{2} \mathrm{q} \%$ & $\mathrm{KKgq} \%$ \\
\hline Tinggi tanaman & $28,63 \pm 2,79$ & $85,67 \pm 8,35$ & 4,10 \\
Jumlah anakan & $-0,42 \pm 0,03^{* *}$ & $-169,54 \pm 12,39^{* *}$ & 0 \\
Bobot gabah isi & $4,30 \pm 0,76^{* *}$ & $48,30 \pm 8,52^{* *}$ & 3,62 \\
Bobot gabah total & $3,93 \pm 0,83^{* *}$ & $40,65 \pm 8,57^{* *}$ & 2,82 \\
Bobot 100 butir gabah isi & $-0,01 \pm 0,00$ & $-44,12 \pm 9,67$ & 0 \\
Jumlah gabah isi & $29023,55 \pm 3091,24^{* *}$ & $78,54 \pm 8,37^{* *}$ & 7,96 \\
Produksi & $0,07 \pm 0,01^{* *}$ & $48,57 \pm 8,52^{* *}$ & 3,63 \\
\hline
\end{tabular}

Tabel 7. Pendugaan ragam genetik, heritabilitas, dan koefisien keragam genetik untuk varietasQTL

\begin{tabular}{lccc}
\hline Peubah & $\sigma^{2} \mathrm{vq} \pm \mathrm{GB}^{2} \mathrm{vq}$ & $\mathrm{h}^{2} \mathrm{vq} \% \pm \mathrm{GBh}^{2} \mathrm{vq} \%$ & $\mathrm{KKgvq} \%$ \\
\hline Tinggi tanaman & $247,28 \pm 49,03 * *$ & $93,26 \pm 18,51^{* *}$ & 12,04 \\
Jumlah anakan & $21,59 \pm 4,47^{* *}$ & $89,57 \pm 18,54^{* *}$ & 15,59 \\
Bobot gabah isi & $61,58 \pm 14,68^{* *}$ & $78,43 \pm 18,70^{* *}$ & 13,69 \\
Bobot gabah total & $89,70 \pm 20,67^{* *}$ & $80,94 \pm 18,66^{* *}$ & 13,47 \\
Bobot 100 butir gabah isi & $0,88 \pm 0,19^{* *}$ & $85,44 \pm 18,59^{* *}$ & 16,20 \\
Jumlah gabah isi & $24325,33 \pm 10584,39^{*}$ & $45,54 \pm 19,81^{* *}$ & 7,29 \\
Produksi & $1,01 \pm 0,24^{*}$ & $78,44 \pm 18,70^{* *}$ & 13,67 \\
\hline
\end{tabular}

Tabel 8. Korelasi variabel pengamatan

\begin{tabular}{|c|c|c|c|c|c|c|}
\hline Variabel & $\begin{array}{l}\text { Jumlah } \\
\text { anakan }\end{array}$ & $\begin{array}{c}\text { Tinggi } \\
\text { tanaman }(\mathrm{cm})\end{array}$ & $\begin{array}{l}\text { Bobot gabah } \\
\quad \text { isi (g) }\end{array}$ & $\begin{array}{l}\text { Bobot gabah } \\
\text { total }(\mathrm{g})\end{array}$ & $\begin{array}{l}\text { Bobot } 100 \text { butir } \\
\text { gabah isi (g) }\end{array}$ & $\begin{array}{l}\text { Jumlah } \\
\text { gabah isi }\end{array}$ \\
\hline Tinggi tanaman & 0,08 & & & & & \\
\hline Bobot gabah isi & $-0,01$ & $-0,17$ & & & & \\
\hline Bobot gabah total & 0,06 & 0,02 & $0,96 * *$ & & & \\
\hline Bobot 100 butir & $-0,04$ & $-0,60 * *$ & 0,21 & 0,050 & & \\
\hline Jumlah gabah isi & -0.06 & $0,49 * *$ & $0,47 * *$ & $0,52 * *$ & $-0,12$ & \\
\hline Produksi & $-0,01$ & $-0,17$ & 1,0 & $0,96 * *$ & 0,21 & $0,47 * *$ \\
\hline
\end{tabular}

\section{KESIMPULAN}

Segregasi fenotipe muncul di lingkungan sawah baru pada tanaman padi varietas IR64 yang merupakan varietas nasional. Segregasi fenotipe terlihat dari parameter tinggi tanaman dan jumlah anakan yang tidak sama pada tanaman padi yang ditanam di lingkungan sawah baru.; keragaman genetik dan heritabilitas yang tinggi terlihat pada semua varietas baik varietas lokal maupun varietas nasional yang ditanam di lingkungan sawah baru dan seleksi langsung ditujukkan oleh parameter produksi, sedangkan seleksi tidak langsung ditujukkan oleh parameter bobot gabah isi, bobot gabah total dan jumlah bulir isi pada varietas padi lokal dan nasional di lingkungan sawah baru.

\section{DAFTAR PUSTAKA}

Falconer, D.S. and T.F.C. Mackay. 1996. Introduction to Quantitative Genetics. 4th eds. Longman England.

Hapsari, R., dan M., Adie. 2010. Pendugaan parameter genetik dan hubungan antarkomponen hasil kedelai. Jurnal Penelitian Pertanian Tanaman Pangan 29(1):18-23.

Pinaria, A., A. Baihaki, R. Setiamihardja, dan A.A. Dradjat. 1995. Variabilitas genetik dan heritabilitas karakter-karakter biomassa 53 genotipe kedelai. Zuriat 6(2):88-92. 
Pradnyawathi, Ni L.M.2012. Evaluasi galur Jagung SMB-5 hasil seleksi massa varietas lokal bali "Berte" pada daerah kering. Jurnal Bumi Lestari 12(1):106-115.
Syukur, S.S., R. Yunianti, dan D.A. Kusumah. 2011.Pendugaan ragam genetik dan heritabilitas karakter komponen hasil beberapa genotipik cabai. J. Agrivigor 10(2):148-156. 